\title{
Global Land Grabbing: A Critical Review of Case Studies across the World
}

\author{
Bin Yang ${ }^{1,2}$ and Jun $\mathrm{He}^{1,3, *(\mathbb{D}}$ \\ 1 National Centre for Borderland Ethnic Studies in Southwest China, Yunnan University, \\ Kunming 650091, China; yangbinht@foxmail.com or yangbin@zafu.edu.cn \\ 2 International College, Zhejiang Agriculture and Forestry University, Hangzhou 311300, China \\ 3 School of Ethnology and Sociology, Yunnan University, Kunming 650091, China \\ * Correspondence: jun.he@ynu.edu.cn; Tel.: +86-871-65034738; Fax: +86-871-65031748
}

check for

updates

Citation: Yang, B.; He, J. Global Land Grabbing: A Critical Review of Case Studies across the World. Land 2021, 10, 324. https://doi.org/10.3390/ land10030324

Academic Editor: Volker Beckmann

Received: 28 January 2021

Accepted: 17 March 2021

Published: 21 March 2021

Publisher's Note: MDPI stays neutral with regard to jurisdictional claims in published maps and institutional affiliations.

Copyright: (c) 2021 by the authors. Licensee MDPI, Basel, Switzerland. This article is an open access article distributed under the terms and conditions of the Creative Commons Attribution (CC BY) license (https:// creativecommons.org/licenses/by/ $4.0 /)$.

\begin{abstract}
Over the past several decades, land investments have dramatically increased to meet global food and biofuel demands, produce industrial commodities, protect environments and develop urban centres. Scholars and media actors have labelled this phenomenon "land grabbing", owing to its many negative impacts. Since existing knowledge was generated from individual case-studies, global land grabbing patterns are relatively underexamined, and broader extrapolations of results to inform land grabbing theories are limited. Thus, there is an urgent need to conduct a large- $N$ analyse on existing knowledge of land grabbing to enhance the understanding of the state-of-the-art knowledge and identify the gaps in research. We conducted a critical review of existing scholarly literature on case studies of land grabbing. Based on formal criteria, we selected 128 case studies from 124 articles out of 252 peer-reviewed articles published since 2007. We examined geographic distribution and commonly referenced topics in existing research and the clarified environmental and socioeconomic outcomes of land grabbing, presenting the most current knowledge on the topic to date. Findings from this research also revealed substantial gaps in the existing literature in terms of conceptualization, methodology and research area. The paper concludes with a call for more interdisciplinary, holistic research that looks at broader regional/temporal contexts and the inclusion of more evidence-based data.
\end{abstract}

Keywords: land acquisition; land investment; crop booming; environmental impacts; socioeconomic impacts; cultural impacts

\section{Introduction}

After the food crisis and increased energy price in 2007-2008, large-scale investments in land dramatically increased to establish commercial crop production in order to meet global food and biofuel demands and produce industrial commodities [1-4]. Later scientific studies indicated that land investments also occurred for biodiversity conservation [5-7], climate mitigation [8,9], watershed protection [10] and urbanisation [11]. Globally, it is estimated that land-related deals have involved around 68 million hectares since 2008 [12], while others estimate the total area involved to be between roughly 45 million [13] and 227 million hectares [14]. Land prices can range from single digits of euros per ha in most cases to upwards of 100 euros per ha in other cases [12]. It is extremely challenging to estimate accurate prices, given differences in international and domestic investors, governments and local elites involved across a wide range of scales and investment types [15]. Moreover, investments generally lack transparency, forcing researchers to rely on webbased media information in existing databases that are difficult to verify [16]. Apart from quantity and scale, land investments have attracted significant attention globally, as there are concerns that many land transactions do not sufficiently consult local land users [17], violate human rights [18,19] and lead to negative social or environmental impacts [20-22]. 
Increasing criticisms levelled at the unsustainability of large-scale land investments, particularly regarding transnational land acquisition, have led to media actors and scholars labelling this phenomenon "land grabbing". The term land grabbing echoes of the colonialism and imperialism of recent history $[1,15,23]$. Currently, the term is widely used by NGOs, activists, international organizations, media actors and scholars who also refer to it as a form of neo-colonial dynamics [23]. According to International Land Coalition, land grabbing is any type of land acquisition that is in violation of human rights, without prior consent of indigenous land users and without consideration of social or environmental impacts [24]. In addition to emphasizing the lack of transparency and democratic decision-making in land deals, other definitions of land grabbing also highlight that investors predominately hail from foreign countries and include a scale of roughly more than 200 ha per deal [25]. However, there are increasing cases of land being grabbed by domestic elites [26,27], even villagers in some instances [28-30], and/or at small scales [5,31,32]. The definition of land grabbing now extends far beyond large-scale land acquisition conducted by foreign actors, as scholarly and local reactions have diversified. Many see land grabs as threats to the lives and livelihoods of local people, while others see economic opportunities for the rural poor [1]. Some scholars, therefore, suggest more neutral terminology to describe the phenomenon, such as "land-based investments" [33]. Currently, scholars also use "common grabbing" as the term, because the majority of land acquisition activities take placing with communal land [34,35].

While land investments are booming in the world, work on land grabbing is also booming in the literature. Apart from numerous individual case studies, international peer-reviewed journals have also published several special issues as collected volumes on land grabbing, such as the Canadian Journal of Development Studies in 2012, The Journal of Peasant Studies in 2012, Globalization in 2013, Third Word Quarterly in 2013, Development and Change in 2013, Geoforum in 2016 and Land in 2021. While there currently is a rich body of literature, existing knowledge of land grabbing has mainly been generated from qualitative case study methodology and has been dominated by case-to-case specificity, resulting in geographical bias and case contextuality. These indepth case studies simply cannot elucidate global patterns [36]. At a global level, although international organizations have also conducted global land grabbing surveys $[12,13,37,38]$, these studies have been aimed at setting up a baseline global database and lack rigorous scientific and theoretical considerations. Furthermore, many global land grabbing surveys are based on web and media information and lack confirmative grounded studies, as argued by Visser and Spoor [16] and Borras Jr et al. [39]. Thus, scientific generalisations to inform theories of land grabbing fail to address the gap between global analysis and local case-studies. Additionally, existing literature on land grabbing has largely been produced by scholars with backgrounds in political economics and political ecology who have focused on political structures and processes, and power relations in land deals. As one would expect, there are unavoidable biases in the methodologies and theories used for data collection and analysis. Some scholars have conducted meta-analyses of scholarly literature on land grabbing. However, those studies focused on specific topics, such as sustainable land deals [40] and common grabs [34] with limited numbers of case-studies included in analysis. Assessments of the accuracy and limitations of existing knowledge are lacking. As such, there is urgent need to conduct a large- $N$ analysis on the existing knowledge of land grabbing to obtain a holistic understanding of the global pattern of "land grabbing" and to advance further research.

To obtain a comprehensive understanding of the state of empirical grounded knowledge on land grabbing, we conducted a critical review on existing scholarly literature on cases of land grabbing through systematic literature research. Under the overall research question, "What is the state-of-the-art knowledge on land grabbing?", we intended to answer three subquestions: (1) What is the geographic distribution and what are the topics of focus in existing research on land grabbing? (2) What are the documented roles of investors and local actors in global land grabbing. (3) What are the observed outcomes of 
land grabbing in environmental, economic and sociocultural aspects. Thereby research aimed to identify current conceptual gaps, methodological gaps and gaps in research targets through a critical review. To do so, we selected 128 case studies from 124 articles out of 252 peer-reviewed articles published since 2007, based on formal criteria. That way, we generated state-of-the-art, empirically grounded knowledge on land grabbing and the characteristics of case study research in this area. This paper is divided into four sections. The following section presents the methodology for the literature search, the criteria of literature selection and the analytic framework for this systematic review. That is followed by the results section. The results section includes three major subsections, including elaboration of the geographic distribution and commonly referenced topics in the existing literature of case studies; discussion of investors and local actors in global land grabbing; and environmental, economic and sociocultural outcomes of land grabbing. The paper concludes by discussing current gaps in the literature and future research directions.

\section{Methodology}

As outlined by Paré et al. [41] and Templier and Paré [42], the aim of this critical review was to critically analyse the extant literature on broad topics to reveal weaknesses, contradictions, limitations and highlight other problems. Following Dell"Angelo et al. [34], a systematic literature selection was performed for comparing already-published case studies. To collect the already-published peer-reviewed scholarly cases, we selected publications from the core collection of Web of Science ${ }^{\mathrm{TM}}$ by searching the following key words: ("land grab*" or "land rush" or "land-based investment" or "large scale land acquisition") and ("case") (on 22 May 2020). We selected publications from core collection of Web of Science, as it is commonly used database for systemic selection of literature in formal procedure and this database contains peer-reviewed publication only, as said by Dell'Angelo et al. [34]. Other databases were not selected for this analysis, as they can include publications which were not peer-reviewed, such as Google Scholar. We selected case studies published after 2007 when the concept of topical "land grabbing" first appeared. In total, 252 articles met the criteria of the search. To present a holistic picture of land grabbing that includes detailed and reliable information, cases were selected to matched the criteria: (1) the case study provided exact land deals as well as impacts on local communities, and (2) the case study was conducted with fieldwork. After reading the articles and evaluating whether they met the criteria for selection, we narrowed our pool down to 124 articles that documented 128 cases (full list found in Supplementary Information). Due to language barriers and mainstream journals largely publishing in English, the limitation was that we only selected English-language publications indexed in Web of Science ${ }^{\mathrm{TM}}$.

We categorised the original 124 articles including 128 cases mainly at the community level as follows: 70 in Africa, 43 in Asia, 12 in Latin America, 2 in post-Soviet Eastern Europe and one in the South Pacific (Figure 1 and Table 1). In addition to the basic information of the selected articles, such as publication year, journal, author and location of the case, cases were also categorised in terms of land deal scale, impacts, local reactions, land deal actors, commonly referenced topics and main topics (Table 1 and Figure 2). For each case study, we identified whether the case elicited positive or negative responses from local communities in terms of economic, sociocultural and environmental impacts; whether the study provided empirical data rather than descriptive portrayals to present changes before and after land deals; and whether there were any analyses targeting the perspectives of investors and so on (Table 1). 


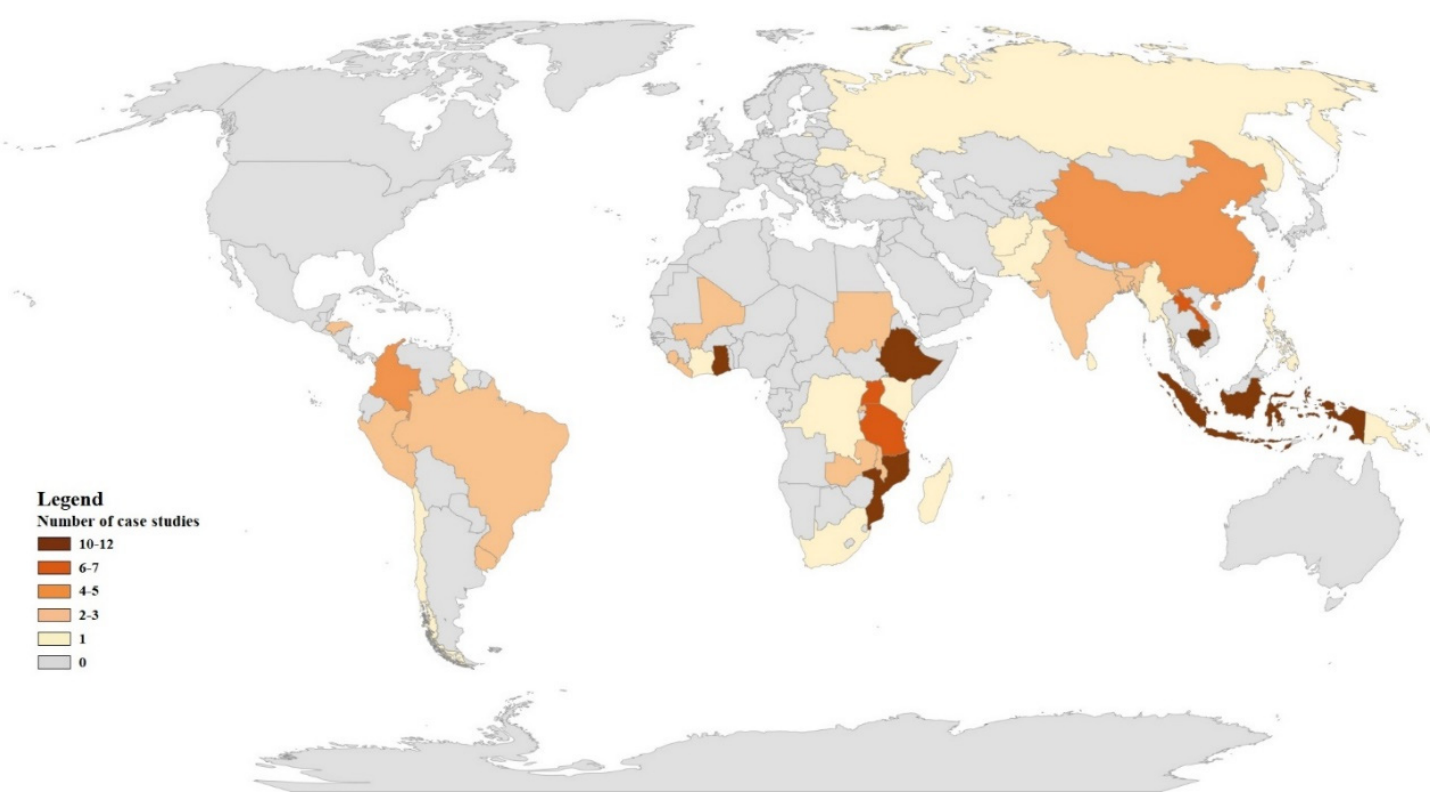

Figure 1. The number of case studies $(n=128)$.

Table 1. Key information of the selected case studies.

\begin{tabular}{|c|c|c|c|c|c|c|c|c|c|c|c|c|c|c|c|c|c|}
\hline \multirow[b]{2}{*}{ Cases } & \multicolumn{3}{|c|}{ Scale of Land Deals } & \multicolumn{3}{|c|}{ Actors of Land Deals } & \multicolumn{2}{|c|}{ Themes } & \multicolumn{4}{|c|}{ Local Reaction } & \multicolumn{2}{|c|}{ Study on Investor } & \multicolumn{2}{|c|}{ Quantitative Data } & \multirow{2}{*}{$\begin{array}{l}\text { Total in } \\
\text { the } \\
\text { Region }\end{array}$} \\
\hline & Large & Both & Small & Foreign & Both & Domestic & Plantation & Others & Negative & Both & Positive & $\begin{array}{c}\text { Not } \\
\text { Clear }\end{array}$ & Yes & No & Yes & No & \\
\hline Africa & 61 & 8 & 1 & 40 & 16 & 14 & 50 & 20 & 31 & 23 & 2 & 14 & 18 & 52 & 9 & 61 & 70 \\
\hline Asia & 33 & 6 & 4 & 13 & 7 & 23 & 28 & 15 & 26 & 11 & - & 6 & 6 & 37 & 2 & 41 & 43 \\
\hline Latin America & 12 & - & - & 1 & 5 & 6 & 6 & 6 & 6 & 4 & 1 & 1 & 4 & 8 & - & 12 & 12 \\
\hline Europe & 2 & - & - & - & 1 & 1 & 1 & 1 & - & 1 & - & 1 & - & 2 & - & 2 & 2 \\
\hline South Pacific & 1 & - & - & 1 & - & - & - & 1 & 1 & - & - & - & - & 1 & - & 1 & 1 \\
\hline Total & 109 & 14 & 5 & 55 & 29 & 44 & 85 & 43 & 64 & 39 & 3 & 22 & 28 & 100 & 11 & 117 & 128 \\
\hline
\end{tabular}

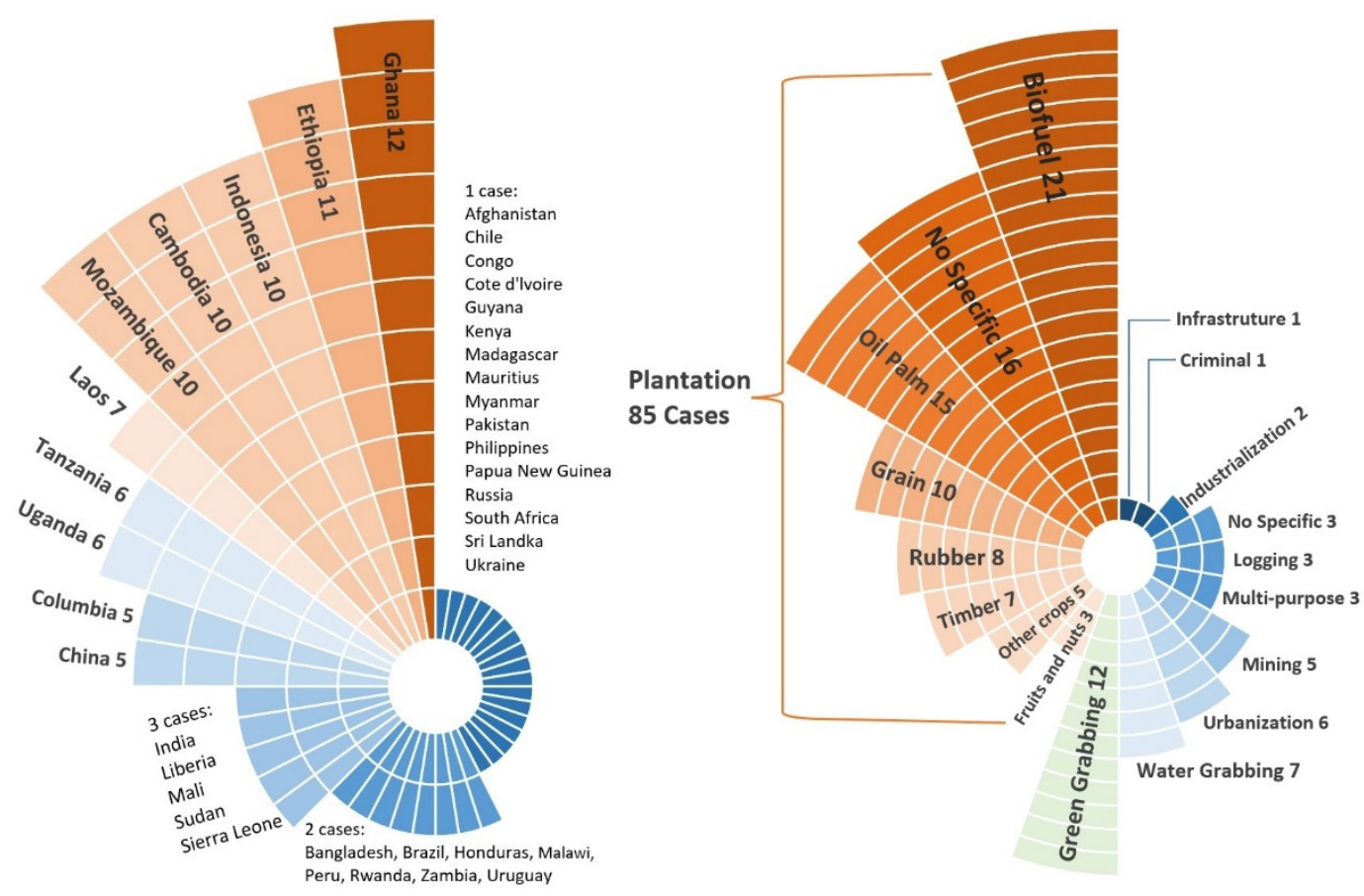

Figure 2. Case locations by country and grabbing types $(n=128)$. 


\section{Results}

\subsection{Geographic Distribution and Commonly Referenced Topics}

Global interest in land grabbing case studies has significantly risen since 2012, and case studies rose six-fold in the period between 2011 to 2012. These cases largely occur in the Global South, particularly in the developing countries of Africa and Asia. The top five countries for case studies were Ghana, Ethiopia, Cambodia, Indonesia and Mozambique. Laos followed with seven cases (Figure 2). All top eight countries under study are low or lower-middle income countries based on World Bank classifications [43]. Those capitalpoor countries have opened their land markets to the Global North and other powerful economies in order to "turn the land into capital"; in addition, the colonized history of these countries evokes particular hints of neo-colonialism and neo-imperialism $[1,15,23,44]$. Two case studies from Europe are located in post-Soviet countries and focus on the unique socioeconomic structural transformation that occurred after the dissolution of the USSR [45,46].

Two-thirds of the 128 case studies feature plantations, especially centring around tropical products, such as biofuel, palm oil, rubber and tropical fruits and nuts (Figure 2). Biofuel is the most popular subject for plantation studies; $90 \%$ of biofuel studies were centred on Africa; meanwhile, the cases from Africa constituted 55\% of the total. The land deals in this region have drawn significant attention since many African countries have long histories of large-scale farming at the behest of colonial powers [47], and now many African countries have allocated large swaths of land for foreign land-based investment [48]; it echoes of the colonialism and imperialism of recent history [15,23]. However, 15 studies published before 2016 took special interest in the boom of biofuels in Africa and their relationship with "peak oil" [26,36]. This trajectory ended when oil prices plunged in 2016. In contrast, oil palm has also attracted many case studies, but the temporal distribution is flatter, given that palm oil demands have stabilised in past years (palm oil is also considered a biofuel species, but in practice it is mainly used in food processing so it is categorized separately). Palm oil studies have mostly been conducted in Indonesia, given the recent rapid growth of Indonesia's palm oil industry, thereby eclipsing Malaysia as the largest palm oil exporter in 2010 and constituting half of total global exports since 2015 [49]. On the contrary, traditional exporters of palm oil with comparative flat growth, such as Malaysia and Papua New Guinea [49], have drawn much less attention. Research on rubber plantations is popular too: Laos and Cambodia have both drawn significant attention. All eight of such cases originated from these two countries, and Laos in particular was the site of six of the eight cases, reflecting the rubber boom in Laos over the last two years. In early 2000s, natural rubber exports from Laos were almost zero, but in 2018 it ranked among the top five in the world [49]. Furthermore, rubber studies also concentrate in Laos because it is an archetypical target country for overseas Chinese investment [50], and many media actors, NGOs and scholars have labelled Chinese investors as quintessential "land grabbers" [33].

Several other case studies have been conducted in the name of grabbing water associated with land, which was also labelled as land grabbing for the purposes of our research. A total of seven cases of water grabbing occurred in parallel with tropical plantation and aquaculture land grabs. Obviously, land investors are not only grabbing land but also its embedded aquatic resources for cultivation [26] or requesting the re-arrangement of water management schemes and institutional designs [51]. Persistent international market demand has also driven the booming of aquatic industries, such as shrimp cultivation [52], that accelerate water grabbing. However, water grabbing tends to become a special issue separate from land grabbing [53], resulting in few gathered water cases in this review.

As for environmental conservation, the term "green grabbing" has also been used in conjunction with land grabbing since 2012 [2]. There were a total of 12 case studies that used the term "green grabbing", including a study examining ecotourism in land grabbing. These studies have focused on the state implementing territorialization in the planning and establishment of national parks [5,54], as well as the discourse of climate change and environmental protection, such as afforestation projects for carbon sequestration $[9,10]$, 
biodiversity conservation [6] or so-called "environmentality" for the same purpose of territorialisation through ecotourism development [7].

Many originally claimed that food security and fuel are the main drivers of contemporary global land grabbing, but later research presented land grabbing as strongly influenced by the boom of other export-oriented crops [55,56]. Only 10 cases studied grain crops $-12 \%$ of total plantation grabbing studies. By contrast, 59 studies on cash crops constituted $69 \%$ of total studies. Thus, we conclude that most research actually focuses on crop booming-related land grabbing, rather than land grabbing related to security concerns.

In addition, there were six case studies of land grabbing driven by urbanisation. The cases from China constitute half of total urbanisation studies, owing to the rapid upswell in rural-urban migration seen in China over the last several decades [57-59]. The remaining case studies occurred in Afghanistan [60], India [61] and Sri Lanka [62]. Surprisingly, no cases from Southeast Asia or Africa were found in the literature, despite the rapid urbanisation and rural-urban migration happening in these regions [11,63-65]. Compared to urbanisation, land grabbing caused by industrialisation and infrastructure development has drawn relatively less attention. Only two case studies involving industrialisation were found, both centring around China for the same reasons driving urbanisation: the first case focused on China as an investor in Mauritius to acquire land for promoting the special economic zone model abroad [66]; and the second one was a domestic case of a county in Jiangxi Province in the central south region of China being used to obtain land for industry park development [67]. Only one case study examined a land grabbing conflict caused by a dam development project in Madhya Pradesh, India [68], despite debates on mega-infrastructure heating up globally.

Land grabbing studies have also focused on the mining industry. There were a total of five cases related to mining. Two studies were from Ghana, where large amounts of land have been allocated for foreign investment in agriculture and mining projects [48]. Moreover, in Ghana, the mining sector, especially gold mining, has historically been at the centre of major land disputes [69]. Gold mining has also ignited land-based conflicts in other mineral-rich countries, such as Peru [70]. Finally, there is one particularly unique study from Colombia that details the ways in which narcotics trafficking involves land grabbing in order to manufacture and transport cocaine and other drugs [71].

\subsection{Investors and Local Actors}

Early analyses of land grabbing focused on foreign actors investing in the land of the host countries, mainly those of the Global South [36]. This is because of the high degree of attention on powerful capital-rich countries seeking land in previously colonised parts of the world, particularly in Africa [72], where land grabbing has been described as a neocolonial push by foreign companies and governments to annex key natural resources [23]. Nevertheless, even in the earliest case studies, land grabbing by domestic elites has also been discussed through the linkage of foreign and domestic capital [26]. In fact, studies including domestic actors or both domestic and foreign actors have constituted a significant proportion of all studies since 2013 (Figure 3). 


\section{Case studies by actors/time}

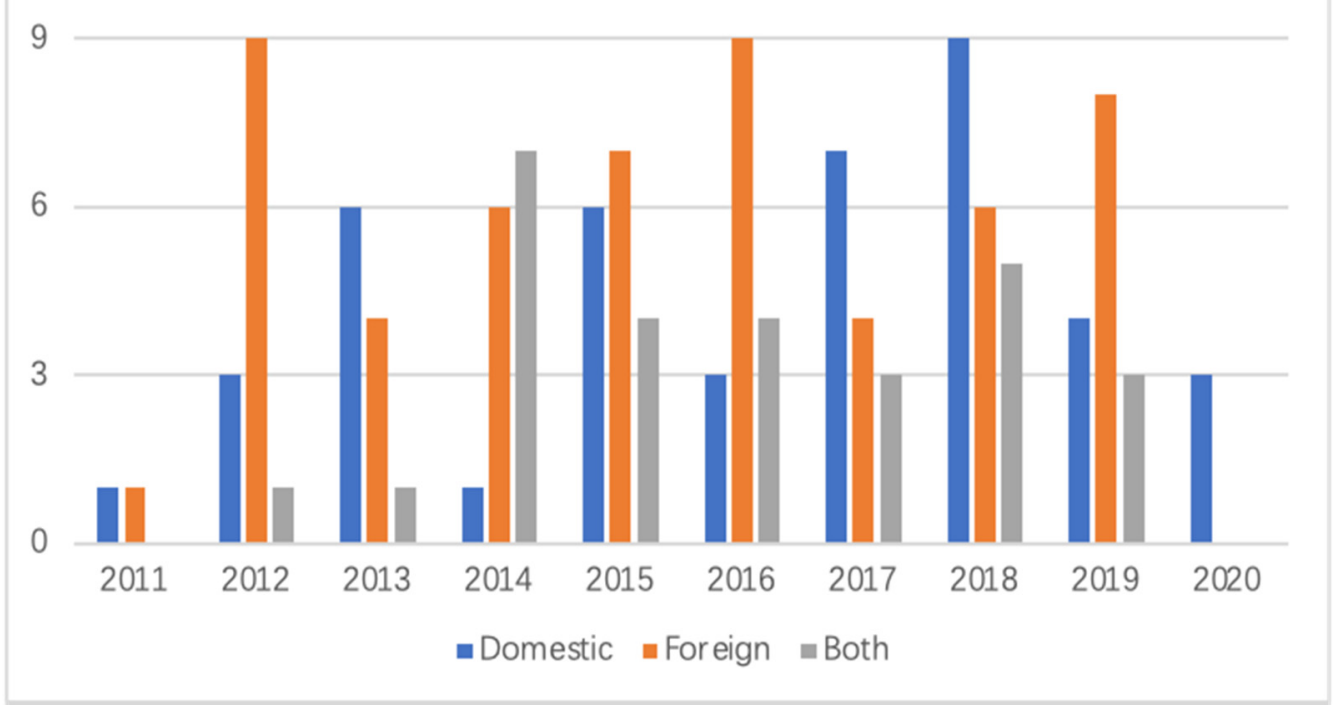

Figure 3. The case studies by actors in different years $(n=128)$.

In total, 55 out of 128 cases focused on foreign actors; 44 were domestic and another 29 indicated that actors were both foreign and domestic (Table 1). Indeed, foreign actors still have garnered the most academic attention due to aforementioned reasons and the sensitive history of foreign regimes controlling outside lands, particularly in postcolonial Africa [73]. Foreign actors are not necessarily a monolith from the Global North, though; there is an emerging "south-south" dynamic featuring economically powerful non-northern countries [1]. The main foreign actors reported in this case review include China, EU nations, the United States, the United Kingdom, India, the United Arab Emirates and Malaysia. However, academic debate on neo-colonialism dropped off in later research. Many studies present institutional explanations and impacts of land grabbing, such as the ways in which the discourse of development introduced by foreign actors working together with host countries reshapes land tenure in developing countries [74-76]. Furthermore, foreign actors have also influenced local customary rights $[77,78]$. (Due to more than one foreign actor in many cases, the number of foreign actors is counted by case. For example, if two foreign actors are stated in one case, each actor will be counted as 0.5 cases in terms of grabber/investor type). Much research has commented on China's important role as foreign grabber/investor. China is the most-cited area, with more than 10 cases, confirming many studies' claim that China is a quintessential "land grabber" - it is capital-rich, land-scarce and invests primarily in resource extraction and production for export; and its investments have accordingly attracted significant attention [33].

Many early discussions on domestic actors focused on the upper-class domestic elites who are tightly linked with foreign capital, such as the elites and oligarchs in Africa [26,73,79] and Russia [45]. Soon afterward, cases studies turned to domestic elites who support gangs, corrupt public servants and members of the military [80,81]. Later, studies targeted those at the grassroots level, such as elites in villages, arguing that local villagers can also be grabbers and are not one homogenous group of victims or resisters $[28,29,48]$. Hence, attention to land grabbing in terms of domestic grabbers/investors can also partially reveal that the trajectory of the studies has changed from debates over foreign capital and control to the issue of land itself.

In addition, many cases focused on the views of local stakeholders, while only 28 cases included investors' perspectives and motives, comprising $22 \%$ of total case studies. Some scholars point to a tendency of current land grabbing studies to overlook investors' motives beyond assuming their vague drive for profit, thereby assuming them to be financial 
predators engaging in land deals that disregard local interests [50,82]. Nevertheless, some scholars present the heterogeneity of land investors in terms of morality, behaviour and other characteristics [83]. Meanwhile, these scholars also show that not all land grabbers/investors ignore local interests-some are keenly aware of the comprehensive impacts for local communities and try to consider imperatives beyond pure profit [50,83-85]. In fact, in early discussions, Azadi et al. [86] indicated different types of land deals. The study categorised land deals into four types: lose-lose; lose-win; win-lose; win-win.

In the early stage of the land grabbing research, attention was largely focused on large land deals made by transnational corporations [55]. Case studies support the trend. Across the 108 case studies, $84 \%$ were large scale and all focused on hotspot countries, while only five cases discussed small-scale land deals in Bangladesh, Tanzania, Laos, China and Myanmar. Another 14 case studies included both large and small scales. Although small-scale land deals have been studied since 2012 [5,80], deep analyses of small-scale land deals did not occur until after 2015, suggesting the need for more academic attention on small-scale land deals [28]. Soon after, several studies postulated that small-scale grabbing can have far-reaching implications [31]. This is primarily because the number of investors in small-scale deals is significantly higher than those involved in large-scale deals. Such deals can exert a more serious negative impact on local communities [29] and are a significant driver of agrarian transformation [30].

\subsection{Outcomes of Land Grabbing}

\subsubsection{Economic Outcomes}

Most case studies discussed the economic impacts of land grabbing for local communities, while only 25 cases were unclear or did not mention them (Figure 4). Livelihood changes have been the focus of much attention since early discussions [74,75]. Nearly half of the cases claim that local communities perceive negative impacts for their livelihoods, which led to resistance to land deals in 30 cases. Negative perceptions mainly focus on little or no compensation and lost farming opportunities, as well as land deals falling short of pledges to offer employment opportunities. Many cases analysed this situation. For example, a case from Rwanda reported by Ansoms [87] showed an example of zero compensation for land dispossession, since land access was governed by informal rights and claimed by the government as sellable state property. Local people lost out on agricultural opportunities and then unwillingly had to begin contract farming. Many were forced to seek off-farm work, resulting in high opportunity costs. Following Ansoms, more than 10 cases also revealed no compensation for lost informal land rights. Though compensated, Borras Jr. et al. [26] reported a case from Mozambique that did not offer the promised job opportunities. In this case, the biofuel company considered environmental, labour and social safety regulations- few employees could be hired because of strict standards, but local people had already partially lost access to the land for agricultural products.

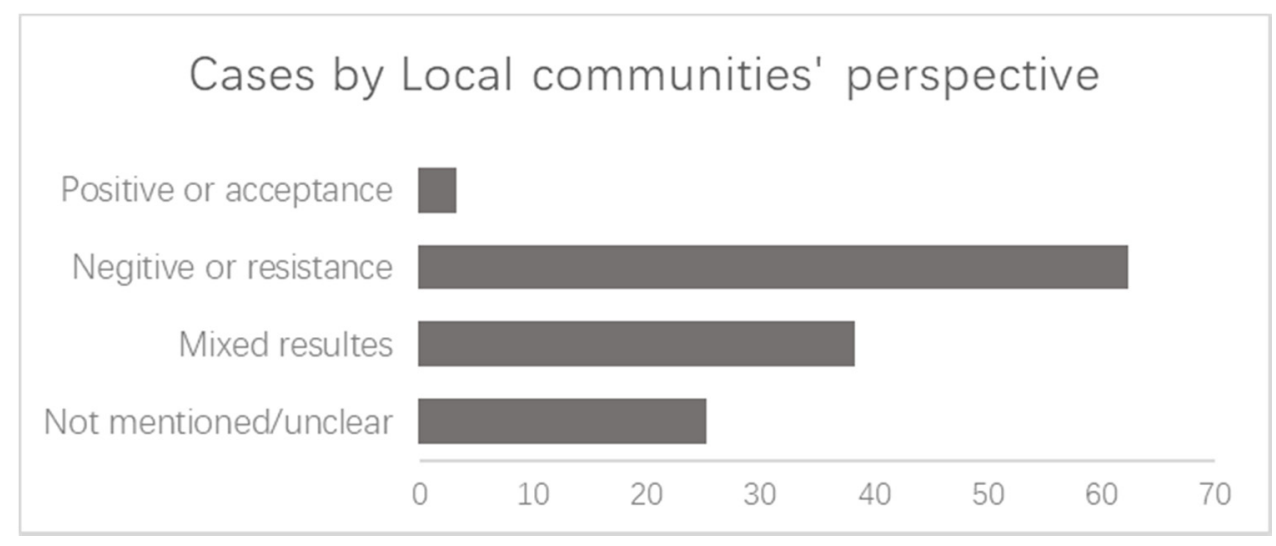

Figure 4. Cases by the perspective of the local community $(n=128)$. 
Another 38 cases indicated mixed outcomes on livelihoods. Many emphasized the heterogeneity of communities in which different members had different views and benefits from similar land deals [46,88,89]. Even similar members can attain different benefits and react unevenly at different stages of land investment. This layer of nuance is often overlooked. Rietberg and Hospes [90] reported such a case from Kalimantan, Indonesia. Local communities had supported a land deal for a large oil palm plantation before land conversion started in 2007 owing to the investment company promising higher standards of living resulting from the increased economic activity. However, the people who gave the land over commented on the negative impacts after the plantation's completion in 2010 , since the promise was not realized. Some scholars have argued that in general land investments improve livelihood but exacerbate inequalities, such as men benefitting more than women and the wealthy more than the impoverished. Bottazzi et al. [91] studied the case of a biofuel production company in northern Sierra Leone whose investment led to the exacerbation of inequality in the area. After surveying 882 households, the study concluded that impacted villages received a clear increase in total monetary income, benefiting from land rental fees and compensation, and employment opportunities offered by the company. However, land rental fees and compensation were concentrated among the formerly rich landlords, whose average monetary incomes increased $89 \%$, while tenants' increased only $48 \%$. Meanwhile, access to wage labour was mainly granted to men rather than womenless than $2 \%$ of women who suffered reduced agricultural production opportunities affected by large-scale plantations were re-employed, whereas $20 \%$ of men gained access to the job opportunities.

Although the authors of most case studies were critical of the negative or complex livelihood impacts of land investments, two cases presented positive impacts for local communities as a win-win situation when managed well. One fish-farming project reported by Azadi et al. [86] in Uganda indicated that the project partially solved the problem of over-fishing in Lake Victoria while the Chinese investors gained access to local markets. Both sides profited, ideally resulting in a sustainable food production system. The other of a biofuel plantation in Ghana reported by Schoneveld and German [74] showed the acceptance by local communities of a land deal due to their high expectations of "development" and "modernisation", and the authors further assessed that serious risks might emerge if implementation were to not be carried out as planned. The case studied investments of a biofuel plantation in Ghana, indicating that overall income from agricultural activities decreased; however, people increased their cash incomes through off-farm jobs as labourers in the plantation. At the same time, though, 70-90\% of vulnerable groups, especially women who used to collect timber products as their main income, experienced significant income declines, since the plots they would have used for activities were already absorbed by the plantation.

Despite these figures, most case studies on livelihood impacts are ethnographic studies. Accounts rarely provide concrete data, but rather rely on descriptive narratives to reach conclusions. Only 11 cases provided quantitative insights into local livelihood changes, including four cases that applied specialised quantitative analysis methods [89,92-94]. The other seven cases at least presented and analysed quantitative data based on fieldwork rather than relying upon descriptive portrayals for drawing research conclusions $[87,91,95,96]$. Some scholars, such as Jiao, call for more deep quantitative analyses in order to reveal clearer, more nuanced pictures of changes and impacts as well as equitable alternatives to land grabbing rather than tabula rasa "land grabbing" and land use changes [94].

In total, these assembled case studies present detailed homogeneities and heterogeneities related to the economic impacts of land grabbing. However, the studies reveal different local community altitudes toward similar circumstances in the process of land grabbing. Possible explanations of this phenomenon require deeper cross-society studies that consider cultural and economic makeup at local and regional levels, along with opportunities costs, policies and political institutes. More importantly, future studies might need to compare different cases with and without land grabbing in order to present holistic 
economic impacts. In addition, case studies mainly focus on livelihood impacts at the local community level but rarely take into account governmental revenue and broader economic changes resulting from the land deals. Hence, this paper calls for more comparative studies of economic impacts at local and regional levels.

\subsubsection{Environmental Impact}

Economic impacts attract the lion's share of scholarly attention. Only 78 cases reported the environmental impacts of land grabbing, typically mentioning in isolation the degradation of soil and land, contamination and deforestation and biodiversity and ecosystem loss, rather than focusing on environmental impacts as a holistic topic. Nevertheless, many cases indicate that when monocultures replace food crops and tropical mosaic landscapes, environmental issues worsen across the board. For example, soil and land degradation as well as land and water contamination have been reported as consequences of banana farming in northern Laos [31] and biofuel plantations in Ghana [97] due to intensive use of fertilizer, pesticides and plastics. In Cambodia, Jiao reported that 5000 ha of forestland was replaced by acacia and cassava plantation in one commune [94], while oil palm plantations replaced 14,000 ha of rainforest at a small village in Ghana [96] and even more in East Kalimantan, Indonesia [98]. Deforestation and ecosystem damage are also reported as results of land grabbing for logging and mining. In Mozambique, Lagerkvist reported uncontrolled logging due to secretive bilateral land agreements [99], and mining has also led serious deforestation and biodiversity loss in Zambia [100] and Ghana. Only 12\% of Ghana's rainforest remains due in large part to open-pit gold mining [69].

At the same time, land grabbing in urban areas has also caused serious water contamination as well as biodiversity and ecosystem loss. For example, Siciliano [57] reported that the rapid urbanisation process in Shanghai, the largest city in China in terms of population, has caused dramatic biodiversity and ecosystem loss rurally, since the original wetland island was converted for industrial use to meet the needs of the growing metropolis. In Bangladesh, the delta wetland became subsumed in the rapidly expanding urban area, transforming the waterways and leading to urban flooding; at the same time, housing and industry developments on the former wetland released wastewater into the river without purification, leading to downstream water salinity problems [80]. Some land grabs do not take land directly from local communities but cause air and water pollution in the near vicinity. Li and Pan [67] reported how an industrial park project created industrial pollution that caused dispossession of land and water in central-southern China. In this case, collective-owned forestland had been leased for metal production with proper compensation, with villagers retaining full control of their farmland. However, the metal companies discharged raw sewage and harmful emissions at night to avoid environmental air quality monitoring. As a result, crop yield and underground water were both seriously affected, causing many villagers to abandon their farmland and even homes.

On the other hand, several case studies have revealed that environmental impacts of some biofuel projects are not simply positive or negative. The classic example is that biofuel projects may benefit the earth, but deforestation carried out in its name is harmful. A biofuel case in Tanzania reported by Mwakaje [101] mentioned that biofuel production mitigates emissions but introduces deforestation in plantation host countries. Apart from criticism of the negative environmental impacts, many cases of green grabbing reveal partially positive environmental results $[7,8,102]$, as some land grabbing projects are in pursuit of conservation. For example, many African counties enclose local land under the discourse of forest protection, or for national park building, such as Tanzania [8], Kenya [103] and Mozambique [102,104], while private land is occasionally also enclosed for conservation purposes, as reported by Holmes in Southern Chile [6]. Leach et al. [8] and Tienhaara [9] reported that commercial biochar and carbon forest projects promoted restoration of degraded lands in Uganda and Liberia. However, green grabbing has imposed restrictions on traditional resources and undermined customary indigenous rights. Those projects have caused dispossession $[9,104]$ and epochal changes in traditional cultures and forms of 
livelihood [5], and are also labelled as territorialisation-as expanding state control of land as a political priority rather than a conservation endeavour [5,54].

Similarly to many studies on economic outcomes of land grabbing, environmental impacts in case studies are often overlooked and are in urgent need of robust data. Many case studies only provide cursory overviews. Compared to attention on the economic outcomes of land grabbing, environmental impact evaluations need more interdisciplinary research in terms of combining biochemistry, soil and crop sciences, geography, sociology and anthropology. For instance, soil $\mathrm{pH}$, fertility monitoring, water eutrophication data collection and remote sensing for land use change analyses, when taken in aggregate with economic and ethnographic studies, can provide comprehensive and far superior environmental pictures of regions affected by land grabbing.

\subsubsection{Social and Cultural Impacts}

Social and cultural impacts of land grabbing are significant since traditional livelihoods and customary or informal rights are dramatically affected by it. All case studies present sociocultural impacts for local communities in terms of changes to customary or informal rights and traditional livelihoods; structural loss, displacement and dispossession; the gap between rich and poor; elite capture; gender inequality; and more. Approximately $60 \%$ of case studies concluded that net negative impacts result from land grabbing for local communities, while almost no case indicated any positive social and cultural impacts, excluding economic benefits. Our cases focused on sociocultural issues related to customary or informal rights, dispossession or displacement, elite capture and gender problems.

The cases revealed that the land tenure in rural areas is usually informal, and is historically embedded in customary or informal rights in many developing countries; land grabbing, particularly large-scale land deals driven by outsiders, has reshaped customary or informal systems in terms of formalisation of tenure. Customary or informal rights affected by land grabbing or so-called commons grabbing [34,35], therefore, have drawn significant attention; 41 cases discussed local communities losing communal land control or access. For example, Ansoms [87] reported on a biofuel project in Rwanda in which the plantation enclosed large-scale swampland used by locals to fish, graze and sometimes cultivate. However, locally perceived legitimacy of informal, historically embedded land rights clashed with the government's development plan for swamplands, since the landscape constitutes $10 \%$ of the land-scare country. After the legality of the swampland belonging to the state was confirmed, the local community lost land access as a result of land concession to the biofuel company. Lu and Schönweger [50] also reported a similar story in Laos in which local communities lost access to the "empty land" where they used to do shifting cultivation that was later claimed by the government as state property and converted for rubber development. In many African countries, even when customary tenure has been recognized and governed by customary law, local communities have still lost customary rights and common land control as consequence of opposing legislated processes for large-scale land acquisition [105]. Apart from land grabbing for agriculture and green energy, such as biofuel, there are also many areas being grabbed for conservation purposes. For example, Bluwstein [7] reported how the ecotourism reinforced but eventually appropriated village communal land rights through a neoliberal environmentality in Tanzania.

Furthermore, loss of land access, control and customary rights has changed the traditional livelihoods of local communities. For example, palm oil and pulp tree plantations replaced the traditional collection of forest products in Indonesia, and indigenous people have become manual labourers in plantations now [106,107]; and rubber plantations replaced shifting cultivation in Laos [108]. Parallel with traditional livelihood changes, traditional governance structures have also been changed as a consequence of modern state institutional expansion-national agencies have replaced or been positioned above local authorities, particularly in marginalised areas that historically have lacked national oversight. For example, Indonesia expanded palm oil plantations in remote East Kali- 
mantan while advancing modern state institutions, leading to the fall of "adat" (custom) authority [22]. The Malawi government did something similar via sugarcane plantation expansion [109]. In Guyana, the state declared forests as state property by legislation and put under the control of state forestry services these so-called "political forests" [110]. At the same time, local communities found solutions by cleverly using their bargaining power to maintain land ownership and traditions de facto in negotiations related to land grabbing. In Kenya, Chabeda-barthe and Haller [103] also presented that local communities resisted land grabbing by applying for formal cooperative farm status to maintain their traditional livelihoods.

Overlapping with loss of land access, control and customary rights, land grabbing leads to displacement and dispossession. Many case studies on green grabbing revealed that indigenous people have been forced to relocate once their original residences were declared within the boundaries of national parks $[5,76,104]$ or claimed for environmental restoration [9]. In other cases, the local poor faced forceful eviction after loss of land control [27]. In the Malawi case reported by Bae [109], the main reason for the discontentment of the local community was not the process of displacement per se, but the worsening of their living and working environments brought on via land grabbing repercussions (such as increased competition for jobs). In some cases, local communities are not displaced from the land, but rather indirectly dispossessed of its resources or value post-change [59]. Access to land in itself, therefore, does not guarantee security for smallholders [111]. Many cases presented dispossession exacerbating the gaps between the rich and poor, elites and nonelites and genders. This phenomenon is also called accumulation by dispossession $(\mathrm{ABD})$, a concept adapted and redeployed by geographer David Harvey from Marx's notion of "primitive accumulation" [112]. It defines neoliberal capitalism as resulting in a centralisation of wealth and power in the hands of a few by dispossessing the public and private entities of their wealth or land.

In the aforementioned Sierra Leone case, the phenomenon of elite capture in which rich landlords gained more than the poor from large-scale plantations was elaborated upon. Other cases present even more extreme inequity in urban areas. For example, a case study from Cambodia [27] presented how the urban poor become trapped in poverty. Cambodia conducted land reform and created land legislation after the civil war. However, lack of governance and corruption led to unequal land distribution. Rich and powerful men gradually became landlords and later evicted the local poor after real estate development led to increased evaluation of the land. Many urban poor become trapped in poverty as landless and homeless while rich landlords experienced dramatic windfalls from urban expansion. Similar situations have also been reported in the mining sector of Indonesia by Bachriadi and Suryana [113] in that the oil field developed by ExxonMobil in East Java enriched the already elite class but dispossessed the local poor.

Meanwhile, other cases indicated that land grabbing-led dispossession further strengthened gender inequality; gender issues, thus, have drawn much attention, particularly portrayals of women as fundamentally excluded from the decision-making and benefit sharing processes, while the twin processes of "modernisation" and "formalisation" have been accompanied by masculinisation, weakening the bargaining positions of women. For example, Julia and White [114] reported that women lost both land tenure rights and sources of income due to the large-scale oil palm plantation in West Kalimantan, Indonesia. The case showed that like many community members, women shared in land ownership, as the customary system did not feature gender differentiation in land inheritance practices. Moreover, women used to catch fish and collect other forest products to supplement their incomes, granting them heightened financial autonomy. However, the large-scale palm oil plantation led to the formalisation of land tenure by the state, and implementing the practice of a "family head" system excluded women's participation, eroding women's right to land de jure due to men typically registering as the family heads. At the same time, the palm oil plantation forbidding women's fishing and collection activities from the land eroded women's right to land de facto. The loss of resource tenure and autonomy has 
undermined the position and livelihood of indigenous women in this already patriarchal community.

The collected case studies present informative social and cultural impacts of land grabbing. As mentioned above, almost no case indicated positive social and cultural impacts, excluding economic benefits. More comprehensive, interdisciplinary case studies that include long-term progressive fieldwork during land investment, rather than repeating case studies on a single issue or presenting opposition for opposition's sake, are required to acquire a holistic picture of land grabbing and its myriad, far-reaching implications.

\section{Discussions}

The contemporary phenomenon of "land grabbing" drew significant academic attention after the food and energy crisis in 2007-2008. At the early stage, there were few empirical studies due to lacking fundamental information of the land deals; many studies thus were macroscopic in nature and were based on online and media information [16]. Later, more grounded case studies were conducted in response to the calling for more evidence-based research to inform the debate of whether "land grabbing" should be considered as a development opportunity or threat to the global poor. Even evidence in case studies can be marshalled for either "right" or "wrong" [39]. Nevertheless, in addition to online and media information, case studies are sine qua non for generating information in order to study "land grabbing" holistically. The current collection of case studies contributes great value to the global discourse, present compelling information on land grabbing in terms of actors, geographic distribution, themes, economic and environmental outcomes, social and cultural impacts and many other respects. However, large gaps remain that weaken authorial arguments and create a fragmented reading experience.

First, there is a lack of analysis of multi-faceted effects of land grabbing, as observed by Borras Jr and Franco [39] and Gerber and Haller [35]. This partially stems from lack of comprehensive and comparative studies. Most cases only focus on a single issue in one place and certain historical period, but rarely consider the issue in the surrounding environment and socio-cultural political context, let alone the region's particular history and experience with land deals, all of which would shed light on the particular significance of certain land grab deals. In addition, most authors chose to focus on analysis at the community level, ignoring regional changes that might restructure communities. While land investment can cause dispossession for local communities, the potential also exists to increase regional government revenue, which can be invested into programs that benefit the common folk, such as education and infrastructure, while providing higher income generation opportunities from off-farm work and ecotourism, as suggested by the stateimposed afforestation program in China [115] and national park-building in Africa [116]. Neglecting this nuance, most case studies focus on criticizing the negative impacts to refute the line of thinking that purports land deals function as purely beneficial processes that deliver crucial developmental opportunities to the global poor. Thus, the lack of a holistic perspective with which to examine multi-faceted effects renders much existing research myopic in scope. Future case studies may need more structured designs to highlight comprehensiveness and comparison rather than simply documenting cases of land grabbing.

Second, recent cases are dominated largely by descriptive ethnographic research, lacking quantitative methods and analyses. Among the 124 articles, there were only four that used an applied quantitative approach $[89,92-94]$ and three with combinations of quantitative and qualitative $[91,95,96]$ approaches. Thus, economic and environmental outcomes are less quantitatively examined and lack conclusive, empirical evidence. Without evidential data to present changes in livelihoods and cash incomes as well as transformations in social welfare programs during land grabbing, it is difficult to arrive at any reliable conclusions. The data on environmental impacts are even more inadequate. The existing literature largely has not utilised data from rigorous scientific analysis, such as changes in soil $\mathrm{pH}$ and fertility, water runoff and eutrophication, air quality indices, forest cover and 
biomass produced. The quantitative studies require interdisciplinary collaboration between researchers with strong backgrounds in biochemistry, soil and crop sciences, geography, economics and sociology. Recent case studies rarely feature interdisciplinary fieldwork; political economists and political ecologists dominate the literature. Moreover, Gerber and Haller [35] was one of the few to provide a multi-year observation; longitudinal research is largely missing to examine the dynamics and long-term effects on the environment and local livelihoods. This is different from other existing research on land governance, for which that longitudinal and interdisciplinary approach has been widely applied $[117,118]$. Hence, the integration of quantitative methods and an interdisciplinary approach are both required to add value to any future land grabbing research.

Third, analysis of broader multi-stakeholder involvement and the heterogeneity of actors involved in land investment is insufficient. Our research findings indicated that there is a tendency to ignore the perspectives of land investors in case studies. Data were mostly collected from indigenous people, governmental officials and NGOs, but less attention was paid to the voices of the investors. Explaining this is the widely held assumption that investors are predominantly motivated by a vague drive for profit, thereby engaging in predatory pursuits of land deals that disregard local interests, as argued by Keene et al. [82]. Lack of data from investors and companies partially resulted from their unwillingness to be involved in interviews, as observed by Gerber and Haller [35]. However, land deals engage both investors and local stakeholders, and moreover, investors are not a monolithic block; they are far more diverse than current researchers claim in terms of behavioural differences and motivations for land deals [83]. Therefore, analyses of investors are equally important for better understanding the patterns and consequences of land deals, as suggested by $\mathrm{Lu}$ [119]. This could help construct a many-voiced story, rather than privileging one voice at the expense of others. While there are challenges to involving investors and companies in research, a researcher's social skills and long-term involvement in the field could help to set up relations with the business sector, as suggested in value chain studies [120].

Fourth, there is little attention given to non-agricultural land deals. As mentioned in the findings, most cases focused on land deals for large-scale plantations in rural areas, while few examined urban areas-even academically rich topics such as the rapid urbanisation and rural-urban migration around the mega cities of China, India, Southeast Asia and Africa and the complex re-structuring of land use and local livelihoods in suburban areas that attends such vast societal upheaval [11,63,65,121-123]. In 2010, over half of the global population was officially classified as urban, marking the first time in human history the urban population exceeded the rural-largely driven by the urbanisation of developing countries [124]. The World Bank data presented the rapid urbanisation over the past two decades in Southeast Asia and Sub-Sahara Africa [125], and surprisingly, there are very few cases of land grabbing driven by urbanisation in the two regions. In general, current case studies confirm the tendency that Zoomers et al. [11] claimed-that global land grabbing debates have ignored land investments taking place in the context of rapid urbanisation. Additionally, non-agricultural land deals being made for mega-infrastructure developments for green energy have little attention [126,127]. A broader consideration of land grabbing is thus needed to consider it in all sectors [35,128,129], particularly in the context of the current reform in developing countries [130].

Supplementary Materials: The following are available online at https:/ / www.mdpi.com/2073-445 X/10/3/324/s1.

Author Contributions: Conceptualization, methodology, and validation, B.Y. and J.H.; formal analysis, investigation and data curation, B.Y.; writing—original draft preparation, B.Y. and J.H; writingreview and editing, B.Y. and J.H.; visualization, B.Y.; supervision, J.H.; project administration, J.H.; funding acquisition, J.H. All authors have read and agreed to the published version of the manuscript.

Funding: This research received financial support from China International Development Research Network (CIDRN) (project number 20200110), the National Natural Science Foundation of China (project number 72063037) and the Ministry of Education of China (project number 16JJD850015). 
Acknowledgments: The initial Idea of this review was benefited from discussion with Xiaobo Hua from Kyoto University, and an early draft of this paper received valuable comments from an academic editor and four anonymous reviewers as well as English editing by Austin Smith.

Conflicts of Interest: The authors declare no conflict of interest.

\section{References}

1. Borras, S.M., Jr.; Hall, R.; Scoones, I.; White, B.; Wolford, W. Towards a better understanding of global land grabbing: An editorial introduction. J. Peasant Stud. 2011, 38, 209-216. [CrossRef]

2. Fairhead, J.; Leach, M.; Scoones, I. Green grabbing: A new appropriation of nature? J. Peasant Stud. 2012, 39, 237-261. [CrossRef]

3. Mcmichael, P. The land grab and corporate food regime restructuring. J. Peasant Stud. 2012, 39, 681-701. [CrossRef]

4. De Schutter, O. How not to think of land-grabbing: Three critiques of large-scale investments in farmland. J. Peasant Stud. 2011, 38, 249-279. [CrossRef]

5. Gardner, B. Tourism and the politics of the global land grab in Tanzania: Markets, appropriation and recognition. J. Peasant Stud. 2012, 39, 377-402. [CrossRef]

6. Holmes, G. What is a land grab? Exploring green grabs, conservation, and private protected areas in southern chile. J. Peasant Stud. 2014, 41, 547-567. [CrossRef]

7. Bluwstein, J. Creating ecotourism territories: Environmentalities in Tanzania's community-based conservation. Geoforum 2017, 83, 101-113. [CrossRef]

8. Leach, M.; Fairhead, J.; Fraser, J. Green grabs and biochar: Revaluing African soils and farming in the new carbon economy. J. Peasant Stud. 2012, 39, 285-307. [CrossRef]

9. Tienhaara, K. The potential perils of forest carbon contracts for developing countries: Cases from Africa. J. Peasant Stud. 2012, 39, 551-572. [CrossRef]

10. Scheidel, A.; Work, C. Forest plantations and climate change discourses: New powers of 'green' grabbing in Cambodia. Land Use Policy 2018, 77, 9-18. [CrossRef]

11. Zoomers, A.; Van Noorloos, F.; Otsuki, K.; Steel, G.; Van Westen, G. The rush for land in an urbanizing world: From land grabbing toward developing safe, resilient, and sustainable cities and landscapes. World Dev. 2017, 92, 242-252. [CrossRef]

12. Land Matrix. Available online: https://landmatrix.org/list/deals (accessed on 31 December 2020).

13. Deininger, K.; Byerlee, D. Rising Global Interest in Farmland: Can it Yield Sustainable and Equitable Benefits? The World Bank: Washington, DC, USA, 2011.

14. Oxfam, Land and Power. Available online: https://policy-practice.oxfam.org/resources/land-and-power-the-growing-scandalsurrounding-the-new-wave-of-investments-in-1-142858/ (accessed on 22 September 2011).

15. Margulis, M.E.; McKeon, N.; Borras, S.M., Jr. Land grabbing and global governance: Critical perspectives. Globalizations 2017, 10, 1-23. [CrossRef]

16. Visser, O.; Spoor, M. Land grabbing in post-Soviet Eurasia: The world's largest agricultural land reserves at stake. J. Peasant Stud. 2011, 38, 299-323. [CrossRef]

17. Oberlack, C.; Tejada, L.; Messerli, P.; Rist, S.; Giger, M. Sustainable livelihoods in the global land rush? Archetypes of livelihood vulnerability and sustainability potentials. Glob. Environ. Chang. 2016, 41, 153-171. [CrossRef]

18. Wisborg, P. Human rights against land grabbing? A reflection on norms, policies, and power. J. Agric. Environ. Ethics 2013, 26, 1199-1222. [CrossRef]

19. Thuon, R. Holding corporations from middle countries accountable for human rights violations: A case study of the Vietnamese company investment in Cambodia. Globalizations 2018, 15, 152-167. [CrossRef]

20. Selfa, T.; Bain, C.; Moreno, R. Depoliticizing land and water "grabs" in Colombia: The limits of Bonsucro certification for enhancing sustainable biofuel practices. Agric. Hum. Values 2014, 31, 455-468. [CrossRef]

21. Dwyer, M.B. The formalization fix? Land titling, land concessions and the politics of spatial transparency in Cambodia. J. Peasant Stud. 2015, 42, 903-928. [CrossRef]

22. Fujiwara, E. The Impact of the Oil Palm on Adat Social Structure and Authority: The Case of the Medang People, Indonesia. Asia Pac. J. Anthropol. 2020, 21, 140-158. [CrossRef]

23. Hall, R. Land grabbing in Southern Africa: The many faces of the investor rush. Rev. Afr. Political Econ. 2011, 38, 193-214. [CrossRef]

24. International Land Coalition. Global Assembly, Tirana, Albania. Available online: http://www.landcoalition.org/about-us / aom2011/tirana-declaration (accessed on 27 May 2011).

25. Rulli, M.C.; Saviori, A.; D’Odorico, P. Global land and water grabbing. Proc. Natl. Acad. Sci. USA 2013, 110, 892-897. [CrossRef] [PubMed]

26. Borras, S.M., Jr.; Fig, D.; Suárez, S.M. The politics of agrofuels and mega-land and water deals: Insights from the ProCana case, Mozambique. Rev. Afr. Political Econ. 2011, 38, 215-234. [CrossRef]

27. Rudi, L.M.; Azadi, H.; Witlox, F.; Lebailly, P. Land rights as an engine of growth? An analysis of Cambodian land grabs in the context of development theory. Land Use Policy 2014, 38, 564-572. [CrossRef]

28. Kandel, M. Politics from below? Small-, mid-and large-scale land dispossession in Teso, Uganda, and the relevance of scale. J. Peasant Stud. 2015, 42, 635-652. [CrossRef] 
29. $\mathrm{Xu}, \mathrm{Y}$. Land grabbing by villagers? Insights from intimate land grabbing in the rise of industrial tree plantation sector in Guangxi, China. Geoforum 2018, 96, 141-149. [CrossRef]

30. Woods, K.M. Smaller-scale land grabs and accumulation from below: Violence, coercion and consent in spatially uneven agrarian change in Shan State, Myanmar. World Dev. 2020, 127, 104780. [CrossRef]

31. Friis, C.; Nielsen, J.Ø. Small-scale land acquisitions, large-scale implications: Exploring the case of Chinese banana investments in Northern Laos. Land Use Policy 2016, 57, 117-129. [CrossRef]

32. Ango, T.G. "Medium-Scale" Forestland Grabbing in the Southwestern Highlands of Ethiopia: Impacts on Local Livelihoods and Forest Conservation. Land 2018, 7, 24. [CrossRef]

33. Hofman, I.; Ho, P. China's 'Developmental Outsourcing': A critical examination of Chinese global 'land grabs' discourse. J. Peasant Stud. 2012, 39, 1-48. [CrossRef]

34. Dell'Angelo, J.; D'odorico, P.; Rulli, M.C.; Marchand, P. The tragedy of the grabbed commons: Coercion and dispossession in the global land rush. World Dev. 2017, 92,1-12. [CrossRef]

35. Gerber, J.D.; Haller, T. The drama of the grabbed commons: Anti-politics machine and local responses. J. Peasant Stud. 2020, 1-24. [CrossRef]

36. Edelman, M.; Oya, C.; Borras, S.M., Jr. (Eds.) Global Land Grabs: History, Theory and Method; Routledge: London, UK, 2016.

37. GRAIN, Land Grabbing and the Global Food Crisis-Presentation. Available online: https://grain.org/en/article/4164-landgrabbing-and-the-global-food-crisis-presentation (accessed on 16 December 2011).

38. Von Braun, J.; Meinzen-Dick, R.S. Land Grabbing" by Foreign Investors in Developing Countries: Risks and Opportunities; IPFRI: Washington, DC, USA, 2009.

39. Borras, S.M., Jr.; Franco, J.C. Global land grabbing and political reactions 'from below'. Third World Q. 2013, 34, 1723-1747. [CrossRef]

40. Vandergeten, E.; Azadi, H.; Teklemariam, D.; Nyssen, J.; Witlox, F.; Vanhaute, E. Agricultural outsourcing or land grabbing: A meta-analysis. Landsc. Ecol. 2016, 31, 1395-1417. [CrossRef]

41. Paré, G.; Trudel, M.C.; Jaana, M.; Kitsiou, S. Synthesizing information systems knowledge: A typology of literature reviews. Inf. Manag. 2015, 52, 183-199. [CrossRef]

42. Templier, M.; Paré, G. A framework for guiding and evaluating literature reviews. Commun. Assoc. Inf. Syst. 2015, 37, 112-137. [CrossRef]

43. World Bank Blog. New World Bank Country Classifications by Income Level: 2020-2021. Available online: https://blogs. worldbank.org/opendata/new-world-bank-country-classifications-income-level-2020-2021 (accessed on 1 July 2020).

44. Dwyer, M. Turning Land into Capital: A Review of Recent Research on Land Concessions for Investment in Lao PDR; Land Issues Working Group: Vientiane, Laos, 2007.

45. Visser, O.; Mamonova, N.; Spoor, M. Oligarchs, megafarms and land reserves: Understanding land grabbing in Russia. J. Peasant Stud. 2012, 39, 899-931. [CrossRef]

46. Mamonova, N. Resistance or adaptation? Ukrainian peasants' responses to large-scale land acquisitions. J. Peasant Stud. 2015, 42, 607-634. [CrossRef]

47. Baglioni, E.; Gibbon, P. Land grabbing, large-and small-scale farming: What can evidence and policy from 20th century Africa contribute to the debate? Third World Q. 2013, 34, 1558-1581. [CrossRef]

48. Nyantakyi-Frimpong, H.; Bezner Kerr, R. Land grabbing, social differentiation, intensified migration and food security in northern Ghana. J. Peasant Stud. 2017, 44, 421-444. [CrossRef]

49. THE ATLAS OF ECONOMIC COMPLEXITY. Available online: https:/ /atlas.cid.harvard.edu/ (accessed on 31 December 2020).

50. Lu, J.; Schönweger, O. Great expectations: Chinese investment in Laos and the myth of empty land. Territ. Politics Gov. 2019, 7, 61-78. [CrossRef]

51. Hertzog, T.; Poussin, J.C.; Tangara, B.; Kouriba, I.; Jamin, J.Y. A role playing game to address future water management issues in a large irrigated system: Experience from Mali. Agric. Water Manag. 2014, 137, 1-14. [CrossRef]

52. Afroz, S.; Cramb, R.; Grünbühel, C. Exclusion and Counter-exclusion: The Struggle over Shrimp Farming in a Coastal Village in Bangladesh. Dev. Chang. 2017, 48, 692-720. [CrossRef]

53. Mehta, L.; Veldwisch, G.J.; Franco, J. Water grabbing? Focus on the (re) appropriation of finite water resources. Water Altern. 2012, 5, 193-468.

54. Sanchez-Ayala, L.; Areiza-Tapias, A. Conservation and people's livelihoods in Colombia. GeoJournal 2019, 84, 1429-1445. [CrossRef]

55. Hall, D. Land grabs, land control, and Southeast Asian crop booms. J. Peasant Stud. 2011, 38, 837-857. [CrossRef]

56. Akram-Lodhi, A.H. Contextualising land grabbing: Contemporary land deals, the global subsistence crisis and the world food system. Can. J. Dev. Stud./Rev. Can. D'études Du Dév. 2012, 33, 119-142. [CrossRef]

57. Siciliano, G. Rural-urban migration and domestic land grabbing in China. Popul. Space Place 2014, 20, 333-351. [CrossRef]

58. Ho, P. The 'credibility thesis' and its application to property rights: (In) secure land tenure, conflict and social welfare in China. Land Use Policy 2014, 40, 13-27. [CrossRef]

59. Kan, K. Accumulation without dispossession? Land commodification and rent extraction in peri-urban China. Int. J. Urban Reg. Res. 2019, 43, 633-648. [CrossRef] 
60. Miszak, N.; Monsutti, A. Landscapes of power: Local struggles and national stakes at the rural-urban fringe of Kabul, Afghanistan. J. Peasant Stud. 2014, 41, 183-198. [CrossRef]

61. Doshi, S.; Ranganathan, M. Contesting the unethical city: Land dispossession and corruption narratives in urban India. Ann. Am. Assoc. Geogr. 2017, 107, 183-199. [CrossRef]

62. Hettiarachchi, M.; Morrison, T.H.; McAlpine, C. Power, politics and policy in the appropriation of urban wetlands: The critical case of Sri Lanka. J. Peasant Stud. 2019, 46, 729-746. [CrossRef]

63. Satterthwaite, D.; McGranahan, G.; Tacoli, C. Urbanization and its implications for food and farming. Philos. Trans. R. Soc. B Biol. Sci. 2010, 365, 2809-2820. [CrossRef]

64. Thuzar, M. Urbanization in Southeast Asia: Developing smart cities for the future? In Regional Outlook; ISEAS Publishing: Singapore, 2011; pp. 96-100. [CrossRef]

65. Güneralp, B.; Lwasa, S.; Masundire, H.; Parnell, S.; Seto, K.C. Urbanization in Africa: Challenges and opportunities for conservation. Environ. Res. Lett. 2017, 13, 015002. [CrossRef]

66. Cowaloosur, H. Land grab in new garb: Chinese special economic zones in Africa. Afr. Identities 2014, 12, 94-109. [CrossRef]

67. Li, H.; Pan, L. Expulsion by pollution: The political economy of land grab for industrial parks in rural China. Globalizations 2020, 18, 1-13. [CrossRef]

68. Kabra, A.; Mahalwal, S. The micropolitics of dispossession and resistance: Case study of a proposed Dam in central India. Dev. Chang. 2019, 50, 1509-1530. [CrossRef]

69. Andrews, N. Land versus livelihoods: Community perspectives on dispossession and marginalization in Ghana's mining sector. Resour. Policy 2018, 58, 240-249. [CrossRef]

70. Hirsch, E. Investment's rituals: "Grassroots" extractivism and the making of an indigenous gold mine in the Peruvian Andes. Geoforum 2017, 82, 259-267. [CrossRef]

71. McSweeney, K.; Wrathall, D.J.; Nielsen, E.A.; Pearson, Z. Grounding traffic: The cocaine commodity chain and land grabbing in eastern Honduras. Geoforum 2018, 95, 122-132. [CrossRef]

72. Daniel, S. Situating private equity capital in the land grab debate. J. Peasant Stud. 2012, 39, 703-729. [CrossRef]

73. Chinsinga, B.; Chasukwa, M.; Zuka, S.P. The political economy of land grabs in Malawi: Investigating the contribution of Limphasa Sugar Corporation to rural development. J. Agric. Environ. Ethics 2013, 26, 1065-1084. [CrossRef]

74. Schoneveld, G.C.; German, L.A.; Nutakor, E. Land-based investments for rural development? A grounded analysis of the local impacts of biofuel feedstock plantations in Ghana. Ecol. Soc. 2011, 16, 10. [CrossRef]

75. Beekman, W.; Veldwisch, G.J. The evolution of the land struggle for smallholder irrigated rice production in Nante, Mozambique Phys. Chem. Earth Parts A/B/C 2012, 50, 179-184. [CrossRef]

76. Hagen, R.V.; Minter, T. Displacement in the Name of Development. How Indigenous Rights Legislation Fails to Protect Philippine Hunter-Gatherers. Soc. Nat. Resour. 2020, 33, 65-82. [CrossRef]

77. Boamah, F. Imageries of the contested concepts "land grabbing" and "land transactions": Implications for biofuels investments in Ghana. Geoforum 2014, 54, 324-334. [CrossRef]

78. Finau, G.; Jacobs, K.; Chand, S. Agents of alienation: Accountants and the land grab of papua new guinea. Account. Audit. Account. J. 2014. ahead-of-print. [CrossRef]

79. Fairbairn, M. Indirect dispossession: Domestic power imbalances and foreign access to land in Mozambique. Dev. Chang. 2013, 44, 335-356. [CrossRef]

80. Feldman, S.; Geisler, C. Land expropriation and displacement in Bangladesh. J. Peasant Stud. 2012, 39, 971-993. [CrossRef]

81. Edelman, M.; León, A. Cycles of Land Grabbing in Central America: An argument for history and a case study in the Bajo Aguán, Honduras. Third World Q. 2013, 34, 1697-1722. [CrossRef]

82. Keene, S.; Walsh-Dilley, M.; Wolford, W.; Geisler, C. A view from the top: Examining elites in largescale land deals. Can. J. Dev. Stud./Rev. Can. D'études Du Dév. 2015, 36, 131-146. [CrossRef]

83. Kish, Z.; Fairbairn, M. Investing for profit, investing for impact: Moral performances in agricultural investment projects. Environ. Plan. A Econ. Space 2018, 50, 569-588. [CrossRef]

84. Cook, S.; Lu, J.; Tugendhat, H.; Alemu, D. Chinese migrants in Africa: Facts and fictions from the agri-food sector in Ethiopia and Ghana. World Dev. 2016, 81, 61-70. [CrossRef]

85. Neimark, B.D. Biofuel imaginaries: The emerging politics surrounding 'inclusive'private sector development in Madagascar. J. Rural Stud. 2016, 45, 146-156. [CrossRef]

86. Azadi, H.; Houshyar, E.; Zarafshani, K.; Hosseininia, G.; Witlox, F. Agricultural outsourcing: A two-headed coin? Glob. Planet. Chang. 2013, 100, 20-27. [CrossRef]

87. Ansoms, A. Large-scale land deals and local livelihoods in Rwanda: The bitter fruit of a new agrarian model. Afr. Stud. Rev. 2013, 56, 1-23. [CrossRef]

88. Gilfoy, K. Land grabbing and NGO advocacy in Liberia: A deconstruction of the 'homogeneous community'. Afr. Aff. 2013, 114, 185-205. [CrossRef]

89. Deininger, K.; Xia, F. Quantifying spillover effects from large land-based investment: The case of Mozambique. World Dev. 2016, 87, 227-241. [CrossRef]

90. Rietberg, P.I.; Hospes, O. Unpacking land acquisition at the oil palm frontier: Obscuring customary rights and local authority in West Kalimantan, Indonesia. Asia Pac. Viewp. 2018, 59, 338-348. [CrossRef] 
91. Bottazzi, P.; Crespo, D.; Bangura, L.O.; Rist, S. Evaluating the livelihood impacts of a large-scale agricultural investment: Lessons from the case of a biofuel production company in northern Sierra Leone. Land Use Policy 2018, 73, 128-137. [CrossRef]

92. Alamirew, B.; Grethe, H.; Siddig, K.H.A.; Wossen, T. Do land transfers to international investors contribute to employment generation and local food security? Int. J. Soc. Econ. 2015, 42, 1121-1138. [CrossRef]

93. Jiao, X.; Smith-Hall, C.; Theilade, I. Rural household incomes and land grabbing in Cambodia. Land Use Policy 2015, 48, 317-328. [CrossRef]

94. Jiao, X.; Pouliot, M.; Walelign, S.Z. Livelihood strategies and dynamics in rural Cambodia. World Dev. 2017, 97, 266-278. [CrossRef]

95. Nasterlack, T.; von Blottnitz, H.; Wynberg, R. Are biofuel concerns globally relevant? Prospects for a proposed pioneer bioethanol project in South Africa. Energy Sustain. Dev. 2014, 23, 1-14. [CrossRef]

96. Ahmed, A.; Abubakari, Z.; Gasparatos, A. Labelling large-scale land acquisitions as land grabs: Procedural and distributional considerations from two cases in Ghana. Geoforum 2019, 105, 191-205. [CrossRef]

97. Adams, E.A.; Kuusaana, E.D.; Ahmed, A.; Campion, B.B. Land dispossessions and water appropriations: Political ecology of land and water grabs in Ghana. Land Use Policy 2019, 87, 104068. [CrossRef]

98. Urano, M. Why the principle of informed self-determination does not help local farmers facing land loss: A case study from oil palm development in East Kalimantan, Indonesia. Globalizations 2020, 17, 593-607. [CrossRef]

99. Lagerkvist, J. As China returns: Perceptions of land grabbing and spatial power relations in Mozambique. J. Asian Afr. Stud. 2014 49, 251-266. [CrossRef]

100. Chilombo, A.; Fisher, J.A.; van Der Horst, D. A conceptual framework for improving the understanding of large scale land acquisitions. Land Use Policy 2019, 88, 104184. [CrossRef]

101. Mwakaje, A.G. Can Tanzania realise rural development through biofuel plantations? Insights from the study in rufiji district. Energy Sustain. Dev. 2012, 16, 320-327. [CrossRef]

102. Milgroom, J. Policy processes of a land grab: At the interface of politics 'in the air'and politics 'on the ground'in Massingir, Mozambique. J. Peasant Stud. 2015, 42, 585-606. [CrossRef]

103. Chabeda-Barthe, J.; Haller, T. Resilience of Traditional Livelihood Approaches Despite Forest Grabbing: Ogiek to the West of Mau Forest, Uasin Gishu County. Land 2018, 7, 140. [CrossRef]

104. Lunstrum, E. Green grabs, land grabs and the spatiality of displacement: Eviction from Mozambique's Limpopo N ational P ark. Area 2016, 48, 142-152. [CrossRef]

105. German, L.; Schoneveld, G.; Mwangi, E. Contemporary processes of large-scale land acquisition in Sub-Saharan Africa: Legal deficiency or elite capture of the rule of law? World Dev. 2013, 48, 1-18. [CrossRef]

106. Gellert, P.K. Palm oil expansion in Indonesia: Land grabbing as accumulation by dispossession. In States and Citizens: Accommodation, Facilitation and Resistance to Globalization; Emerald Group Publishing Limited: Bingley, UK, 2015.

107. Dhiaulhaq, A.; McCarthy, J.F.; Yasmi, Y. Resolving industrial plantation conflicts in Indonesia: Can mediation deliver? For. Policy Econ. 2018, 91, 64-72. [CrossRef]

108. Kenney-Lazar, M. Governing dispossession: Relational land grabbing in Laos. Ann. Am. Assoc. Geogr. 2018, 108, 679-694. [CrossRef]

109. Bae, Y.J. A Displaced Community's Perspective on Land-Grabbing in Africa: The Case of the Kalimkhola Community in Dwangwa, Malawi. Land 2019, 8, 187. [CrossRef]

110. Bulkan, J. Forest grabbing through forest concession practices: The case of Guyana. J. Sustain. For. 2014, 33, 407-434. [CrossRef]

111. Amanor, K.S. Global resource grabs, agribusiness concentration and the smallholder: Two West African case studies. J. Peasant Stud. 2012, 39, 731-749. [CrossRef]

112. Glassman, J. Primitive accumulation, accumulation by dispossession, accumulation by 'extra-economic'means. Prog. Hum. Geogr. 2006, 30, 608-625. [CrossRef]

113. Bachriadi, D.; Suryana, E. Land grabbing and speculation for energy business: A case study of ExxonMobil in East Java, Indonesia. Can. J. Dev. Stud./Rev. Can. D'études Du Dév. 2016, 37, 578-594. [CrossRef]

114. Julia; White, B. Gendered experiences of dispossession: Oil palm expansion in a Dayak Hibun community in West Kalimantan. J. Peasant Stud. 2012, 39, 995-1016. [CrossRef]

115. He, J.; Sikor, T. Notions of justice in payments for ecosystem services: Insights from China's Sloping Land Conversion Program in Yunnan Province. Land Use Policy 2015, 43, 207-216. [CrossRef]

116. Ezebilo, E.E.; Mattsson, L. Socio-economic benefits of protected areas as perceived by local people around Cross River National Park, Nigeria. For. Policy Econ. 2010, 12, 189-193. [CrossRef]

117. He, J. Institutional bricolage in payment for environmental services: Insights from the Sloping Land Conversion Programme in upland communities, Southwest China. Asia Pac. Viewp. 2020. [CrossRef]

118. He, J.; Martin, A.; Lang, R.; Gross-Camp, N. Explaining success on community forestry through a lens of environmental justice: Local justice norms and practice in China. World Dev. 2020, 142, 105450. [CrossRef]

119. Lu, J. Grounding Chinese investment: Encounters between Chinese capital and local land politics in Laos. Globalizations 2021, 18, 422-440. [CrossRef]

120. He, J.; Yang, B.; Dong, M.; Wang, Y. Crossing the roof of the world: Trade in medicinal plants from Nepal to China. J. Ethnopharmacol. 2018, 224, 100-110. [CrossRef] 
121. Murakami, A.; Zain, A.M.; Takeuchi, K.; Tsunekawa, A.; Yokota, S. Trends in urbanization and patterns of land use in the Asian mega cities Jakarta, Bangkok, and Metro Manila. Landsc. Urban Plan. 2005, 70, 251-259. [CrossRef]

122. Song, W.; Deng, X.; Yuan, Y.; Wang, Z.; Li, Z. Impacts of land-use change on valued ecosystem service in rapidly urbanized North China Plain. Ecol. Model. 2015, 318, 245-253. [CrossRef]

123. Pandey, B.; Seto, K.C. Urbanization and agricultural land loss in India: Comparing satellite estimates with census data. J. Environ. Manag. 2015, 148, 53-66. [CrossRef] [PubMed]

124. Beall, J.; Basudeb, G.K.; Kanbur, R. Urbanization and Development: Multidisciplinary Perspectives; Oxford University Press: Oxford, UK, 2010.

125. The World Bank DATA. Available online: https://data.worldbank.org/indicator/SP.URB.TOTL.IN.ZS (accessed on 31 December 2020).

126. Achilba, G.A. Navigating contested winds: Development visions and anti-politics of wind energy in norther Kenya. Land 2019, 8 , 7. [CrossRef]

127. Ryser, S. The anti-politics machine of green energy development: The Moroccan solar project in Ouarzazate and its impact on gendered local communities. Land 2019, 8, 100. [CrossRef]

128. Haller, T.; Käser, F.; Ngutu, M. Does commons grabbing lead to resilience grabbing? The Anti-polices machine of Neo-liberal Agrarian Development and Local response. Land 2020, 9, 220. [CrossRef]

129. Gmür, D. Not affected the same way: Gendered outcomes for commons and resilience grabbing by large-scale forest investers in Tanzania. Land 2020, 9, 122. [CrossRef]

130. He, J.; Kebede, B.; Martin, A.; Gross-Camp, N. Privatization or communalization: A multi-level analysis of changes in forest property regimes in China. Ecol. Econ. 2020, 174, 106629. [CrossRef] 